IZA DP No. 5814

Exponential Growth Bias and Financial Literacy

Johan Almenberg

Christer Gerdes

June 2011 


\title{
Exponential Growth Bias and Financial Literacy
}

\author{
Johan Almenberg \\ Sveriges Riksbank \\ and Ministry of Finance, Sweden \\ Christer Gerdes \\ SOFI, Stockholm University \\ and IZA
}

\section{Discussion Paper No. 5814 \\ June 2011}

IZA

P.O. Box 7240

53072 Bonn

Germany

Phone: +49-228-3894-0

Fax: +49-228-3894-180

E-mail: iza@iza.org

\begin{abstract}
Any opinions expressed here are those of the author(s) and not those of IZA. Research published in this series may include views on policy, but the institute itself takes no institutional policy positions.

The Institute for the Study of Labor (IZA) in Bonn is a local and virtual international research center and a place of communication between science, politics and business. IZA is an independent nonprofit organization supported by Deutsche Post Foundation. The center is associated with the University of Bonn and offers a stimulating research environment through its international network, workshops and conferences, data service, project support, research visits and doctoral program. IZA engages in (i) original and internationally competitive research in all fields of labor economics, (ii) development of policy concepts, and (iii) dissemination of research results and concepts to the interested public.
\end{abstract}

IZA Discussion Papers often represent preliminary work and are circulated to encourage discussion. Citation of such a paper should account for its provisional character. A revised version may be available directly from the author. 
IZA Discussion Paper No. 5814

June 2011

ABSTRACT

\section{Exponential Growth Bias and Financial Literacy ${ }^{\star}$}

The tendency to underestimate the future value of a variable growing at a constant rate, an example of exponential growth bias, has been linked to household financial decision making. We show that exponential growth bias and standard measures of financial literacy are negatively correlated in a representative sample of Swedish adults. Since financial literacy is linked to household decision making, our results indicate that examining the relationship between exponential growth bias and household finance without adequate controls for financial literacy may generate biased results.

JEL Classification: D12, D14

Keywords: exponential growth bias, financial literacy, household finance

Corresponding author:

Christer Gerdes

Swedish Institute for Social Research

Stockholm University

SE-106 91 Stockholm

Sweden

E-mail: Christer.Gerdes@sofi.su.se

\footnotetext{
* The authors thank Anna Dreber Almenberg, Marieke Bos and Magnus Johannesson for helpful comments and Finansinspektionen for providing the data. Johan Almenberg thanks Sveriges Riksbank for financial support.
} 


\section{Introduction}

The tendency to underestimate the future value of a variable growing at a constant rate, an example of exponential growth bias, has been linked to household financial decision making. More biased households borrow more and save less, and are less likely to invest in stocks (Stango and Zinman, 2009).

Financial literacy, a broad measure including the ability to perform basic calculations as well as familiarity with financial products and concepts, also affects these decisions. Less financially literate households borrow more (Lusardi and Tufano, 2009; Agarwal et al, 2009), save less (Lusardi and Mitchell, 2007), and are less likely to participate in the stock market (Banks and Oldfield, 2007; van Rooij et al, 2007, Christelis et al, 2010).

If exponential growth bias is correlated with financial literacy, measuring its effect on financial decisions will generate biased estimates if financial literacy is not controlled for in an adequate way. Previous research has used proxy measures such as ATM use (Stango and Zinman, 2009) or self-assessed knowledge (Eisenstein and Hoch, 2009).

In this paper we examine the link between exponential growth bias and financial literacy, using a nationally representative sample of Swedish adults.

This paper contributes to the literature by being the first to examine this relationship using standard measures of financial literacy, and by including separate measures for basic and advanced financial literacy.

Our main finding is that exponential growth bias, as defined in Stango and Zinman (2009), is negatively correlated with standard measures of financial literacy. This indicates that examinations of the relationship between exponential growth bias and household financial decisions without including adequate controls for financial literacy is likely to generate biased results. Moreover, basic and advanced financial literacy have distinct effects. Controlling for one but not the other is thus still likely to generate biased results.

\section{Data}

Our data is from the 2010 consumer survey commissioned by the Swedish Financial Supervisory Authority. The data was collected through a telephone survey of an independent random sample of approximately 1,300 Swedish residents that are representative of the adult population. For more details, see Almenberg and Widmark (2011).

The survey contains two sets of questions measuring financial literacy that are described in detail in Almenberg and Widmark (2011). The first set measures basic financial literacy, essentially the ability to perform basic calculations. These six questions have been used in the English Longitudinal Study of Ageing (Steel et al, 2003, Banks and Oldfield, 2007) and in the US Health and Retirement Survey (Lusardi and Mitchell, 2007; McArdle et al, 2009). The second set of questions measure advanced financial literacy, in particular familiarity with financial products and concepts. These six questions are largely based on the financial literacy questions designed by Annamaria Lusardi and Olivia Mitchell for the HRS and the ALP (see Lusardi and Mitchell, 2006 and 2007).

The survey also included a question measuring exponential growth bias. Participants were asked to guess the future value of an investment of 100 SEK growing at a compound rate of 7 percent a year for 30 years. ${ }^{1}$ This is standard way of eliciting exponential growth bias (see Eisenstein and

\footnotetext{
1 "Suppose you invest 100 SEK and the interest rate is 7 percent per year. If you don't withdraw any money, how
} much money do you have in this account after 30 years?" 
Hoch, 2009). Survey participants were not expected to try to calculate the answer but simply to make a guess regarding the future value. If exponential growth bias is prevalent, more individuals will underestimate the future value than overestimate it.

\section{Results}

The respondents in our sample clearly display exponential growth bias. The correct answer to question about compound growth is 761 , whereas the median answer is 410 . The respondents are almost twice as likely to underestimate the correct amount than to overestimate it (62 versus 38 percent). 49 percent of the total sample provided an answer to the exponential growth question. Men and individuals with higher education are slightly overrepresented, but the differences are small so the subsample that provided an answer is assumed to be reasonably representative.

Following previous research on exponential growth bias we can express the bias in terms of the parameter $\theta$ in the following equation:

$$
F V=P V^{*}(1+i)^{(1-\theta) t}
$$

The distribution of responses in terms of the parameter $\theta$ is summarized in Figure 1. The flat line between the $6^{\text {th }}$ and the $8^{\text {th }}$ decentile represents individuals that linearized the task, thus estimating $F V=P V^{*}\left(1+i^{*} t\right)$ instead of $F V=P V^{*}(1+i)^{t}$, a result in line with Eisenstein and Hoch (2009).

\section{Figure 1}

Distribution of responses

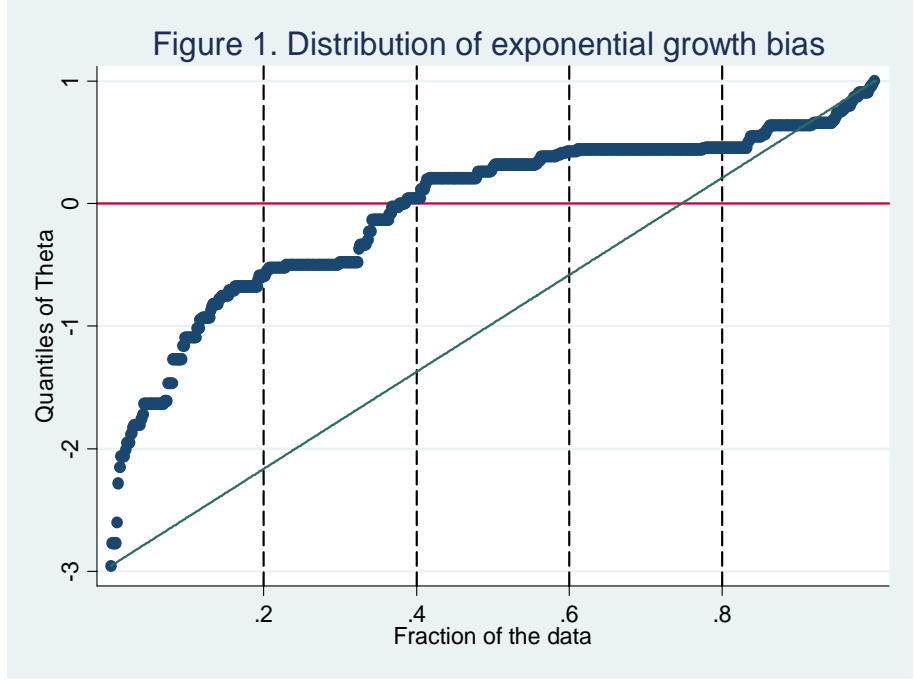

Stango and Zinman (2009) report that among individuals who underestimate the future value, i.e. with $\theta$ in the range $(0,1)$, the magnitude of the bias is correlated with a number of household financial decisions, such as borrowing more and saving less.

We hypothesize that individuals who display larger future value bias will also have lower financial literacy. If this is the case, failing to control adequately for (basic and advanced) financial literacy may generate biased estimates.

We test our hypothesis by regressing $\theta$ on two measures of individual financial literacy. The model has the following form: 


$$
\theta_{i}=a+\beta_{1} F L B_{i}+\beta_{2} F L A_{i}+\beta_{3} X_{i}+\varepsilon_{i}
$$

where $F L B_{i}$ and $F L A_{i}$ are the number of correct answers to the basic and advanced financial literacy questions, respectively, and $X_{i}$ is a vector of controls (sex, age, age ${ }^{2}$, income, education, region of origin). To facilitate comparison with Stango and Zinman (2009) we restrict our sample to individuals with $\theta$ in the range $(0,1)$, i.e. about 62 percent of the sample. ${ }^{2}$

\section{Table 1}

Mean values of variables for individuals.

\begin{tabular}{|c|c|c|c|c|c|c|c|c|c|c|}
\hline & Thos & th estir & ed $\theta$ in th & ange $[0.1$ & & & & All & & \\
\hline Variable & Obs & Mean & Std. Dev. & $\operatorname{Min}$ & $\operatorname{Max}$ & Obs & Mean & Std. Dev. & $\operatorname{Min}$ & $\operatorname{Max}$ \\
\hline Theta & & 0.443 & 0.196 & 0.0001 & 1 & (637) & -0.057 & 0.816 & -4.672 & 2.31 \\
\hline Basic questions & & 5.000 & 1.028 & 1 & 6 & & 4.475 & 1.362 & 0 & 6 \\
\hline Advanced questions & & 4.312 & 1.215 & 0 & 6 & & 3.882 & 1.388 & 0 & 6 \\
\hline male & & 0.593 & & & & & 0.508 & & & \\
\hline age & $(386)$ & 42.57 & 16.837 & 18 & 79 & (1284) & 44.942 & 17.693 & 18 & 79 \\
\hline \multicolumn{11}{|l|}{ Education } \\
\hline primary & & 0.061 & & & & & 0.102 & & & \\
\hline secondary & & 0.34 & & & & & 0.37 & & & \\
\hline vocational & & 0.115 & & & & & 0.144 & & & \\
\hline college & & 0.317 & & & & & 0.274 & & & \\
\hline master & & 0.13 & & & & & 0.081 & & & \\
\hline higher education & & 0.033 & & & & & 0.022 & & & \\
\hline \multicolumn{11}{|l|}{ Income in SEK } \\
\hline$<15 \mathrm{k}$ & & 0.225 & & & & & 0.25 & & & \\
\hline $15-20 \mathrm{k}$ & & 0.087 & & & & & 0.141 & & & \\
\hline $20-25 k$ & & 0.143 & & & & & 0.154 & & & \\
\hline $25-30 \mathrm{k}$ & & 0.156 & & & & & 0.126 & & & \\
\hline $30-35 \mathrm{k}$ & & 0.123 & & & & & 0.092 & & & \\
\hline $35-40 \mathrm{k}$ & & 0.049 & & & & & 0.038 & & & \\
\hline$>40 \mathrm{k}$ & & 0.125 & & & & & 0.081 & & & \\
\hline No answer & & 0.092 & & & & & 0.118 & & & \\
\hline \multicolumn{11}{|l|}{ Region of origin } \\
\hline Nordic origin & & 0.026 & & & & & 0.025 & & & \\
\hline Western origin & & 0.003 & & & & & 0.002 & & & \\
\hline Non-Western origin & & 0.033 & & & & & 0.038 & & & \\
\hline No answer & & 0.026 & & & & & 0.018 & & & \\
\hline $\begin{array}{l}\text { Number of } \\
\text { Observations }\end{array}$ & 391 & & & & & 1302 & & & & \\
\hline
\end{tabular}

The spearman correlation coefficient for exponential growth bias and basic (advanced) financial literacy is -0.15 (-0.11). Both are significantly different from zero at the 5 percent level.

Table 2 summarizes the regression results. The key result is that both basic and advanced financial literacy are negatively correlated with exponential growth bias also when including other covariates.

Columns (1) and (2) show that basic and advanced numeracy have separate and distinct effects: omitting one has little effect on coefficient for the other. Column (3) is the same as (4) except without controlling for education and income. Including these controls has little effect on the coefficients on the two financial literacy measures. In Column (5), we include a dummy variable for one of the basic questions because it involves a two-period compound interest calculation,

\footnotetext{
${ }^{2}$ We elicit exponential growth bias in a slightly different way from Stango and Zinman (2009). They construct their measure indirectly based on two questions, while we use the result of one question that directly measures the bias. This may explain why such a high fraction of their sample, 98 percent, is in this range.
} 
and hence is related to the question eliciting exponential growth bias. The coefficient on the number of correct answers remains essentially unchanged, but the standard error increases. This indicates that the correlation between basic financial literacy and exponential growth bias is not driven by the ability to calculate easier compound interest questions.

\section{Table 2}

OLS regression with the exponential growth bias $(\theta)$ as dependent variable, where $0 \leq \theta \leq 1$.

\begin{tabular}{|c|c|c|c|c|c|}
\hline & (1) & (2) & (3) & (4) & (5) \\
\hline \multicolumn{6}{|l|}{ Financial literacy score } \\
\hline Basic questions & & $-0.028 * * *(0.012)$ & $-0.026 * * *(0.012)$ & $-0.024 * * *(0.012)$ & $-0.024(0.016)$ \\
\hline Advanced questions & $-0.019 * *(0.009)$ & & $-0.017 *(0.009)$ & $-0.017 *(0.009)$ & $-0.017 *(0.009)$ \\
\hline Adjusted R-squared & 0.019 & 0.027 & 0.034 & 0.022 & 0.037 \\
\hline Observations & 386 & 386 & 386 & 386 & 380 \\
\hline
\end{tabular}

Our results are robust to a number of alternative specifications, e.g. exponential or logarithmic transformations of the dependent variable, including missing values for $\theta$, or using a tobit model. These specifications produce qualitatively similar results.

\section{Conclusion}

We show that among individuals that underestimate the future value of a variable that grows exponentially, the magnitude of this bias is negatively correlated with standard measures of both basic and advanced financial literacy.

The recent work by Stango and Zinman (2009) has opened up a promising avenue for research linking exponential growth bias to household finance. The reported links are similar, however, to those between (low levels of financial literacy and economic decision making. Our results emphasize the importance of including adequate controls for both basic and advanced financial literacy. Failure to include such controls is likely to generate bias, most likely in the form of overstating the effect of exponential growth bias on financial decision making. 


\section{References}

Agarwal, S., Driscoll, J., Gabaix, X., Laibson, D., 2009. The Age of Reason: Financial Decisions over the Life-Cycle with Implications for Regulation. Brookings Papers on Economic Activity, 51-117.

Almenberg, J., Widmark, O., 2011. Numeracy and financial literacy among Swedish adults. Working paper.

Banks, J. and Oldfield, Z., 2007. Understanding pensions: Cognitive Function, Numerical Ability and Retirement Saving. Fiscal Studies 28, 143-170.

Christelis, D., Jappelli, T., Padula, M., 2010. Cognitive Abilities and Portfolio Choice. European Economic Review 54, 18-38.

Eisenstein, E. Hoch, S., 2009. Intuitive Compounding: Framing, temporal perspective, and expertise. Fox School of Business working paper, Temple University.

Lusardi, A., Mitchell, O., 2006. Financial Literacy and Planning: Implication for Retirement Wellbeing. Working paper, Pension Research Council, Wharton School, University of Pennsylvania.

Lusardi, A., Mitchell, O., 2007. Baby Boomer Retirement Security: The Role of Planning, Financial Literacy, and Housing Wealth. Journal of Monetary Economics 54, 205-224.

McArdle, J. J., Smith, P., Willis, R., 2009. Cognition and Economic Outcomes in the Health and Retirement Surve. NBER working paper no 15266.

Stango, V. and Zinman, J., 2009. Exponential Growth Bias and Household Finance. Journal of Finance 64, 28072849.

Steel, N., Huppert, F., Williams, B., Melzer, D., 2003. Physical and Cognitive Function, in Marmott, M., Banks, J., Blundell, R., Lessof, C. and Nazroo, J. (eds.), Health, Wealth and Lifestyles of the Older Population in England: the2002 English Longitudinal Study of Ageing. London: Institute for Fiscal Studies. 